\title{
The Development and Determinants of Foreign Exchange Market in Ghana
}

\author{
Mavis Adjei, Bo Yu, Emmanuel Nketiah \\ School of Business, Nanjing University of Information Science \& Technology, Nanjing, China \\ Email: oseikai@hotmail.com, yubo@nuist.edu.cn,nketiah888@hotmail.com
}

How to cite this paper: Adjei, M., Yu, B. and Nketiah, E. (2019) The Development and Determinants of Foreign Exchange Market in Ghana. Open Journal of Business and Management, 7, 1831-1845. https://doi.org/10.4236/ojbm.2019.74126

Received: August 30, 2019

Accepted: September 27, 2019

Published: September 30, 2019

Copyright $\odot 2019$ by author(s) and Scientific Research Publishing Inc. This work is licensed under the Creative Commons Attribution International License (CC BY 4.0).

http://creativecommons.org/licenses/by/4.0/ c) (i) Open Access

\begin{abstract}
This study seeks to examine the determinants of real exchange rate and its overall performance on Ghanaians economy from 1998 to 2016. The study extracted secondary data from the World Development Indicators (WDI) of the World Bank and Bank of Ghana (BoG) websites respectively. The following variables, namely trade openness, public debt, inflation, terms of trade, political stability were used as an independent variable while real exchange rate was the dependent variable. Simple linear regression model with ordinary least method (OLS), was used to analyze the results. The study revealed that trade openness and GDP are the main factors affecting exchange rate in Ghana. Also, the study finds that public debt, terms of trade, political stability had impact but were not statistically significant on real exchange rate. This study recommends Bank of Ghana put efforts to harmonize monetary policies and then proceed to connect these policies with trade and economic growth policies.
\end{abstract}

\section{Keywords}

Real Exchange Rate, Inflation, Trade Openness, Political Stability, Government Public Debt, Term of Trade, Gross Domestic Product

\section{Introduction}

From the 1980s, Ghana embarked on an economic recovery programme (ERP) on trade and foreign exchange liberalization where the "black market" trading was legalized into what is now the foreign exchange (forex) bureaus. This exchange rate management fully took shape between 1983 and 1992 from a rigidly fixed to a flexible exchange rate regime [1] [2].

The exchange rate reform has numerous benefits such as providing tax-type disincentive to exporters, eliminating the parallel market premium and moving 
away from the rigidly fixed and controlled regime towards flexibility. The aim was that the new flexible exchange rate regime would make adjustment of the exchange rate automatic thereby maintaining external competitiveness of the economy. In addition, a flexible exchange rate regime would eliminate the need for the politically risky and difficult devaluations [3] [4].

Since the liberalization of the foreign exchange market, the tempo at which a unit of Ghana's currency (the cedi) exchanges for the US dollar and the other currencies of her major trading associates has seen substantial swings [5] [6]. On the average, the cedi has depreciated in opposition to the US dollar since the adoption of managed floating exchange rate regime in 1986. For example, during the first quarter of 1986, about 0.01 cedis could be exchanged for a dollar; on the other hand, by the end of April 2015, the rate had risen to 3.84, representing a depreciation of $98.7 \%$ over that period.

In private sector-led market-oriented economies such as Ghana, the expectedness of key market prices such as the exchange rate is of significant importance. In the face of uncertainty, private enterprises are incapable to take the long view, preferring to "stay and see" attitude [7].

The exchange rate of the Ghana cedi in opposition to major currencies, (e.g., the US dollar) is quoted as the number of Ghana cedis necessary to buy one US dollar. An unforeseen change in the Ghana cedi/US dollar exchange rate has significant impact on the success of enterprises working in the tradable division of the economy exporters and importers [6].

In order for the proper corrective action to be taken, however, the Bank of Ghana (BoG) must decide whether the unforeseen change is more than the outcome of the policy stance in Ghana or of that of the US Federal Reserve, the equivalent central bank of the United States of America. Determining the response is not easy. One of the broadly used approaches is to observe other exchange rates, for example, in reverence of the British pound and the euro. Thus, if the cedi is depreciating/appreciating falling in value/rising in value alongside all three key major currencies, it is reasonable to end that the unexpected or undesirable transform in the value of the cedi requires corrective action by the BoG [5] [6] [7].

This move has given rise to the concept of the nominal effective exchange rate (NEER) also known as the multilateral exchange rate. It is computed as the weighted average of the exchange rates of the Ghana cedi next to the US dollar, the British pound, and the euro. The weights used by the BoG are the shares of worldwide trade values of imports and exports of Ghana with the particular trading-partner countries [5].

The weight given to the US dollar is the figure of all the shares of trading partners other than the United Kingdom and the European Union. Weights are revised from the moment in time to reflect changes in trading patterns. To make simpler the deliberations here, however, we have used throughout the set of weights specified by the BOG for 2009 [6] [7].

The NEER therefore measures the cost of a "made-in-Ghana" good relative to 
the average cost of the same good of our trading partners, computed on the base of the share of international trade with each partner. It provides a much more complete assessment of the cedi than using any one of the major currencies it interacts with. It provides a much more comprehensive assessment than comparing with any one of them. The interpretation of the NEER is that if the cedi is weaker or depreciated against at least one of the currencies of the trading associates then more cedis is needed to pay for imports [2].

Similarly, a lesser value of the NEER means the cedi is stronger or appreciated against at least one of the currencies of the trading partners, then less cedi is needed to pay for imports. In other words, domestic producers are positioned at a disadvantage against importers in terms of profitability.

Foreign exchange reserve is one of the most vital elements required to stabilize the worth of home currency against foreign currencies. Considering the significant role, a stable currency has on a country's investment drive; it is pertinent to examine the impact of foreign exchange reserve on a country's investment performance [5] [6] [7].

The exchange rate which is the rate at which one country's currency can be exchanged for other currencies has some significant relationship with money supply, inflation, and GDP which determines the exchange rate of a country. But at times, when money supply always has an impact on the exchange rate; this often leads to monetary system losing explanations of the effects on the exchange rate that is the basis of this research [5] [6] [7].

The fluctuation and instability that characterize foreign exchange market and money supply, the compensating explicit and implicit effects on all sectors of the Ghanaian economy, are of the great concern and an extreme interest to the government, exporters and importers, the general citizenry, students and lecturers of economics. The increase in the prices of imported goods has unbearable economic hardships on consumers who have inadequate knowledge of how foreign exchange rate impact on their pattern of consumption and behavior [6] [7].

Local importers are more worried and express fear of been thrown out of businesses as a result of depreciation in the Ghanaian cedi to major international currencies. Therefore, there is a need to check this unstable exchange rate pattern. The main objectives of this study are to examine the determinants of real exchange rate and its overall performance on Ghanaians economy from 1998 to 2016. The outcome of this study is to contribute to monetary and financial policies literature.

\section{Literature Review}

\subsection{Overview of Foreign Exchange Market in Ghana}

\subsubsection{Trade and Exchange Rate Reforms}

From 1983, Ghana embarked on an economic recovery programme (ERP), an important feature which was trade and foreign exchange liberalization. This called for a legalization of the black market into foreign exchange (forex) bu- 
reaus. The shift in the exchange rate management in Ghana took place between 1983 and 1992 from a rigidly fixed to a flexible exchange rate regime [2]. The rigidly fixed exchange rate regime Ghana had pursued before 1983 led to a substantial overvaluation of the cedi, especially in the late 1970s and early 1980s when inflation hovered around 140 percent.

There was a highly developed parallel foreign exchange market which, coupled with the foreign exchange surrender laws, acted as a tax-type disincentive to exporters. The exchange rate reform, therefore, aimed at realigning the overvalued exchange rate, eliminating the parallel market premium and moving away from the rigidly fixed and controlled regime towards flexibility [8] [9].

The hope was that the new flexible exchange rate regime would make adjustment of the exchange rate somewhat automatic thereby maintaining external competitiveness of the economy. In addition, a flexible exchange rate regime would eliminate the need for the politically risky and difficult devaluations. [3].

\subsubsection{Participants and Dealers in Foreign Exchange Market}

The main participants in foreign exchange markets are

1) Retail Clients: Retail Clients deal through commercial banks and authorized agents. They comprise people, international investors, multinational corporations and others who need foreign exchange.

2) Commercial Banks: Commercial banks carry out buy and sell orders from their retail clients and of their own account. They deal with other commercial banks and also through foreign exchange brokers.

3) Foreign Exchange Brokers: Each foreign exchange market centre has some authorized brokers. Brokers act as intermediaries between buyers and sellers, mainly banks. Commercial banks prefer brokers.

4) Central Banks: Under floating exchange rate central bank does not interfere in exchange market. Most of the central banks intervened to buy and sell their currencies to influence the rate at which currencies are traded.

\subsubsection{Types of Foreign Exchange Market}

Foreign Exchange Market is of two types' retail and wholesale market.

1) Retail Market: The retail market is a secondary price maker. Here travelers, tourists and people who are in need of foreign exchange for permitted small transactions, exchange one currency for another.

2) Wholesale Market: The wholesale market is also called interbank market. The size of transactions in this market is extremely large. Dealers are very professionals and are primary price makers. The major participants are Commercial banks, Business corporations and Central banks. Multinational banks are mostly in charge for determining exchange rate.

\subsubsection{Other Participants}

1) Brokers: Brokers have more information and better knowledge of market. They provide information to banks about the prices at which there are buyers and sellers of a pair of currencies. They act as middlemen between the price's 
makers.

2) Price Takers: Price takers are those who buy foreign exchange which they require and sell what they earn at the price determined by primary price makers.

\subsection{Theoretical Review}

\subsubsection{Monetary Approach to Exchange Rate Determination}

The monetary approach postulates that exchange rate is determined in the process of equilibrating the stock or total demand and supply of national currency in each nation. The supply of money in each country is assumed to be determined independently by the nation's monetary authority.

The demand for money depends on the level of real income in the nation, the general price level and the real interest rate. The higher the real income and price, the greater the demand for money balances that individuals and business demand for their day to day transactions or purchases. On the other hand, the higher the interest rate, the greater is the opportunity cost of holding the money.

\subsubsection{Purchasing-Power Parity Theory of Exchange Rate Determination}

This approach is more relevant in the long run than in the short run. The purchasing power parity helps explain the behavior of a currency's exchange value. Changes in relative national price levels decide changes in exchange rates over the long run. The absolute version of the purchasing power parity theory postulates that the exchange rate among two currencies is simply the ratio of the two countries' general price levels [10].

Therefore, the theory predicts that exchange rates are determined by the relative prices, and that change in relative prices will result in changes in exchange rate. A country with high price inflation would experience currency depreciation while a country with low price inflation will experience currency appreciation [11].

\subsubsection{International Fishers Theory of Exchange Rate Determination} International Fisher Theory which states that an estimated change in the current exchange rates between any two currencies is directly proportional to the difference between the two countries' nominal interest rates at a particular time [12].

The real interest rate in a specific economy is independent of monetary variables. With the assumption that real interest rates calculated are the same across the countries, it can also be concluded that the country with lesser interest rate would also have a lower inflation rate [11] [13].

\subsection{Determinants of the Cedi/Dollar Exchange Rate}

\subsubsection{Real Effective Exchange Rate}

Interest rates, inflation and exchange rates are all highly correlated. By manipulating interest rates, central banks exert influence over both inflation and exchange rates, and changing interest rates impact inflation and currency values. Higher interest rates offer lenders in an economy a higher return relative to other countries [14]. 
Therefore, higher interest rates attract foreign capital and cause the exchange rate to rise. The impact of higher interest rates is mitigated, however, if inflation in the country is much higher than in other countries, or if additional factors serve to drive the currency down. The opposite relationship exists for decreasing interest rates-that is, lower interest rates tend to decrease exchange rates.

\subsubsection{Trade Openness (OPEN)}

OPEN measures the extent of openness of the economy measured as the sum of exports and imports (Trade) as a percentage of Gross Domestic Product (GDP). Theoretically, the more opened an economy the higher the rate at which the real exchange rate will depreciate. The implication is that, OPEN is expected to have a negative sign [1].

\subsubsection{Inflation}

Typically, a country with a consistently lower inflation rate exhibits a rising currency value, as its purchasing power increases relative to other currencies. Those countries with higher inflation typically see depreciation in their currency in relation to the currencies of their trading partners. This is also usually accompanied by higher interest rates. Theoretically, inflation is expected to have a positive sign and hence an appreciating effect on the real exchange rate. Thus, an increase in prices may come as result of a rise in demand in both the tradable and non-tradable sectors which can cause the real exchange rate to appreciate [15].

\subsubsection{Current Account Deficits}

The current account is the balance of trade between a country and its trading partners, reflecting all payments between countries for goods, services, interest and dividends. A deficit in the current account shows the country is spending more on foreign trade than it is earning, and that it is borrowing capital from foreign sources to make up the deficit. In other words, the country requires more foreign currency than it receives through sales of exports, and it supplies more of its own currency than foreigners demand for its products. The excess demand for foreign currency lowers the country's exchange rate until domestic goods and services are cheap enough for foreigners, and foreign assets are too expensive to generate sales for domestic interests.

\subsubsection{Public Debt}

Countries will engage in large-scale deficit financing to pay for public sector projects and governmental funding. While such activity stimulates the domestic economy, nations with large public deficits and debts are less attractive to foreign investors. The reason? A large debt encourages inflation, and if inflation is high, the debt will be serviced and ultimately paid off with cheaper real dollars in the future.

In the worst-case scenario, a government may print money to pay part of a large debt but increasing the money supply inevitably causes inflation. Moreover, if a government is not able to service its deficit through domestic means 
(selling domestic bonds, increasing the money supply), then it must increase the supply of securities for sale to foreigners, thereby lowering their prices. Finally, a large debt may prove worrisome to foreigners if they believe the country risks defaulting on its obligations. Foreigners will be less willing to own securities denominated in that currency if the risk of default is great. For this reason, the country's debt rating as determined is a crucial determinant of its exchange rate.

\subsubsection{Terms of Trade}

A ratio comparing export prices to import prices, the terms of trade is related to current accounts and the balance of payments. If the price of a country's exports rises by a greater rate than its imports, its terms of trade have favorably improved. Increasing terms of trade show greater demand for the country's exports. This, in turn, results in rising revenues from exports, which provides increased demand for the country's currency (and an increase in the currency's value). If the price of exports rises by a smaller rate than that of its imports, the currency's value will decrease in relation to its trading partners.

\subsubsection{Political Stability and Economic Performance}

Foreign investors inevitably seek out stable countries with strong economic performance in which to invest their capital. A country with such positive attributes will draw investment funds away from other countries perceived to have more political and economic risk. Political turmoil, for example, can cause a loss of confidence in a currency and a movement of capital to the currencies of more stable countries.

\section{Data and Methodology}

\subsection{Data Collection}

Annual time series data on Ghana 1998 to 2016 drawn from the World Bank Development indicators (WDI) was used in order to achieve the objectives of the study [16]. To get a better view, the study includes foreign direct investment (FDI), Economic growth (as a proxy by real GDP). Trade openness (OPEN) measures the extent of trade openness of the economy measured as the sum of exports and imports as a percentage of GDP. The current account is the balance of trade between a country and its trading partners. The data analysis and statistical software used was STATA 14 [17].

\subsection{Descriptive and Diagnostic Statistics}

In this section, descriptive statistics (i.e. means, standard deviations, minimum and maximum values of variables) and diagnostic testing is based on test for multicollinearity and Pearson correlation were implemented for the research study.

\subsection{Empirical Estimation Model}

Consider a hypothetical data set $\left(x_{1}, x_{2}, x_{3}, x_{n}, y\right)$, and a hypothesized linear re- 
gression model

$$
y_{1}=\beta_{0}+\beta_{1} x_{1 i}+\beta_{2} x_{2 i}+\cdots+\beta_{n} x_{n i}+\varepsilon_{i}
$$

The study used the determinants of the real exchange rate in Ghana focusing by developing a simple real exchange rate model for Ghana as below:

$$
\mathrm{REER}_{t}=\delta_{o}+\delta_{i} \mathrm{INF}_{t}+\delta_{i} \mathrm{OPEN}_{t}+\delta_{i} \mathrm{POL}_{t}+\cdots+u_{t}
$$

REER $=$ Real Exchange Rate, INF = Inflation, OPEN = Trade Openness, POL $=$ Political Stability, PUBLICDEBT $=$ Public Debt, TERMTRADE = Term of Trade and GDP $=$ Gross Domestic Product.

\section{Results and Analysis}

\subsection{Descriptive Statistics}

The descriptive statistics which includes the means, standard deviations, minimum and maximum values of variables. Table 1 presents results of the variables used in the study. The data for the study analysis was retrieved from the World Development Indicators (WDI) from the World Bank with data from 1998-2016 (i.e. 19 years). The results show that the average percentage of real exchange rate is $99.34 \%$, with a maximum percent of 148.58 and a minimum of 72.63 .

Trade openness had a mean value of 83.16 with a minimum value of 61.69 and a maximum of 116.05 . Inflation has a mean percentage of 24.11 with a minimum percent of 13.59 and a maximum of 80.76 . Gross Domestic Product (GDP) has an average of 5.78 with a minimum of 2.18 and a maximum of 14.05. Public debt has a mean of 10.321 with a minimum of 7.069 and a maximum of 15.31. Term of Trade (TERMTRADE) have an average of -14.914 with a minimum of -25.27 and a maximum of -5.60 . The last variable that is Political stability (POL) have an average mean of 0.737 with a minimum of 0 and a maximum of 1 .

\subsection{Diagnostic Test}

\subsubsection{Unit Test}

Figure 1(a) and Figure 1(b) shows the time series plot for natural logarithm transformation of GDP and terms of trade rates from 1998-2016 based on

Table 1. Descriptive statistics for selected dependent and explanatory variables.

\begin{tabular}{cccccc}
\hline Variable & Observations & Mean & Standard deviation & Minimum & Maximum \\
\hline REER & 19 & 99.388 & 18.498 & 72.626 & 148.578 \\
OPEN & 19 & 83.160 & 16.420 & 61.687 & 116.048 \\
INFL & 19 & 24.1089 & 16.795 & 13.588 & 80.755 \\
GDP & 19 & 5.779 & 2.804 & 2.178 & 14.047 \\
PUBLIC & 19 & 10.321 & 2.025 & 7.069 & 15.308 \\
TERMTRADE & 19 & -14.914 & 4.805 & -25.273 & -5.596 \\
POL & 19 & 0.737 & 0.452 & 0 & 1 \\
\hline
\end{tabular}


STATA output. The GDP plots show generally an upward trend with fluctuations. The terms of trade plots exhibit downward trend with fluctuations from 1998-2016 after which it started to trend upwards. This suggests that the movements of the plots indicate that the mean and the variance of both GDP and terms of trade data are changing overtime. This means that the mean is non-constant, and the variance is unstable. The time series plot appears to be stable after the first differencing (i.e. performing a unit test) on the natural logarithm of GDP and terms of trade.

Figure 1(c) and Figure 1(d) shows the time series plot for natural logarithm transformation of annual inflation and trade openness from 1998-2016 based on STATA output. Both inflation and trade openness plots show generally a downward trend with fluctuations. This suggests that the movements of the plots indicate that the mean and the variance of both variables are changing over time. This means that the mean is non-constant, and the variance is unstable. The time series plot appears to be stable after the first differencing (i.e. performing a unit test) on them.

Figure 1(e) and Figure 1(f) shows the time series plot for natural logarithm transformation of government public debt and reel exchange rate from 1998-2016 based on STATA output. The government public debt plots exhibit both upward
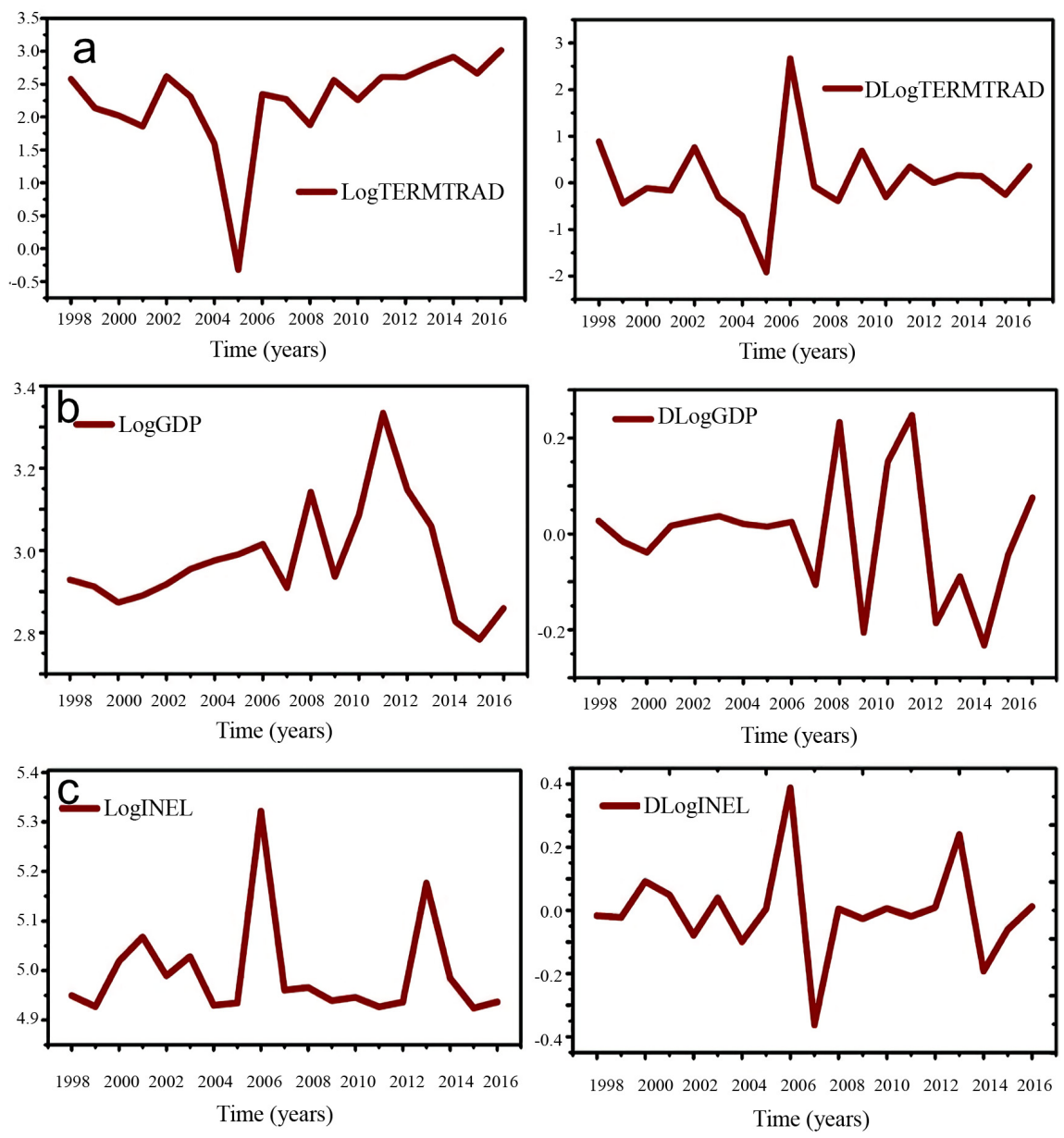

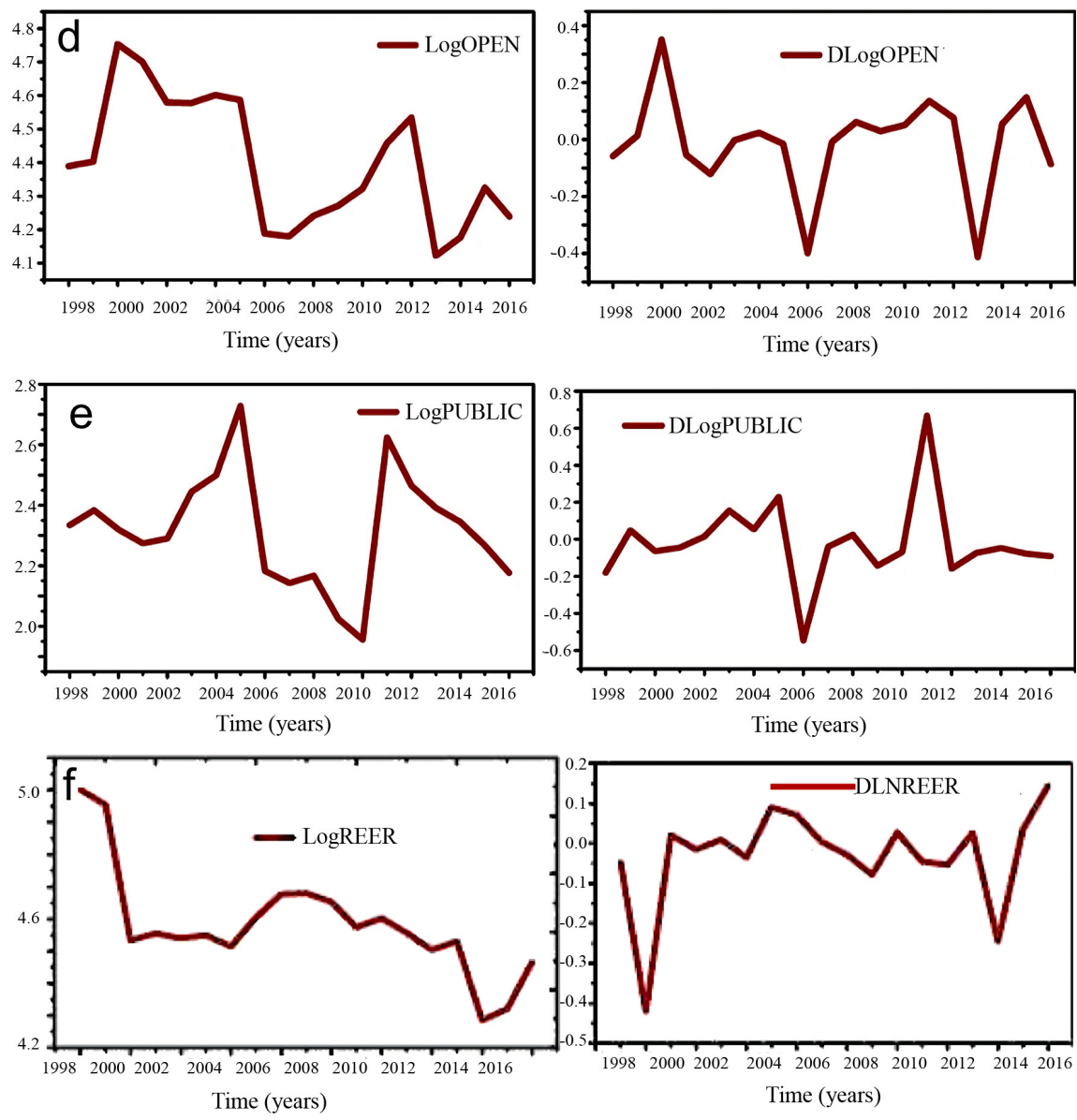

Figure 1. Time series plot of natural logarithm of (a) annual Gross Domestic Product (GDP) and first difference of natural logarithm of GDP, (b) annual Terms of Trade (TERMTRAD) and (b) first difference of natural logarithm of TERMTRAD of (c) annual inflation (INF) and first difference of natural logarithm of annual INFL, (d) annual Trade Openness (OPEN) and first difference of natural logarithm of OPEN, (e) Government Public Debt (PUBLIC) and first difference of natural logarithm of PUBLIC, (f) Real Exchange Rate (REER) and first difference of natural logarithm of REER from 1998-2016.

and downward trend with fluctuations over the period. The movements of the plots indicate that the mean and the variance of the exchange rates data are changing overtime. This means that the mean is non-constant, and the variance is unstable. The time series plot appears to be stable after the first differencing (i.e. performing a unit test) on them.

\subsubsection{Multicollinearity Test}

The study used multicollinearity on regression estimates to assess the effects of different degrees of multicollinearity using variance inflation factor (VIF) [18]. The decision criteria are that if the VIF is greater than 10 then there exists multicollinearity and vice versa.

The general hypotheses:

$H_{0}$ : there is no multicollinearity on regression estimates

$H_{a}$ : there is multicollinearity on regression estimates 
From the results shown in Table 2, the analysis of different degrees of multicollinearity showed the impacts of different degrees of multicollinearity on regression estimates using the variance inflation factor (VIF) [18]. This VIF factor measures the inflation in the variances of the parameter estimates due to multicollinearity potentially caused by the correlated predictors. This is essential when at least two highly correlated predictors are assessed simultaneously in a regression model. If the VIF is greater than 10 then there exist multicollinearity and vice versa. The results showed that the null hypothesis is rejected, which means that there is no evidence of multicollinearity.

\subsubsection{Pearson Correlation Test}

The null hypothesis was that there no relationship between real exchange rate and the explanatory variables. The results from Table 3 showed that Trade openness (OPEN) have a moderately negative $(\mathrm{P}=5.95)$ with real exchange rate. The negative relationship indicates that an increase in trade openness decrease real exchange rate. The negative sign is expected because theoretically, the more opened an economy the higher the rate at which the real exchange rate will depreciate.

The remaining variables showed weak relationship with real exchange rate. For example, inflation, terms of trade and political stability showed very weak

Table 2. Multicollinearity results for all variables.

\begin{tabular}{ccc}
\hline Variable & VIF & $1 /$ VIF \\
\hline PUBLIC & 2.48 & 0.403 \\
OPEN & 1.90 & 0.526 \\
INFL & 1.75 & 0.571 \\
TERMTRADE & 1.73 & 0.579 \\
GDP & 1.68 & 0.594 \\
POL & 1. & 0.712 \\
Mean VIF & & \\
\hline
\end{tabular}

Table 3. Pearson correlation among explanatory variables used in the regression analysis.

\begin{tabular}{cccccccc}
\hline Variables & REER & OPEN & INFL & GDP & PUBLIC & TERMTRADE & POL \\
\hline REER & 1 & & & & & & \\
OPEN & -0.594 & 1 & & & & & \\
INFL & 0.150 & -0.504 & 1 & & & & \\
GDP & 0.327 & 0.043 & 0.200 & 1 & & & \\
PUBLIC & -0.039 & 0.420 & -0.354 & 0.433 & 1 & & \\
TERMTRADE & 0.026 & -0.480 & 0.431 & -0.062 & -0.552 & 1 & \\
POL & 0.243 & -0.343 & -0.023 & -0.109 & 0.079 & 0.169 & 1 \\
\hline
\end{tabular}

*Significance at 0.05 . 
but positive relationship with real exchange rate. Gross Domestic Product (GDP) show a positive correlation coefficient of 0.327 which indicates that a higher GDP leads to a stronger real exchange rate and this positive sign is expected.

There is a weak and a negative relationship between real exchange rate and public debt. The reason is that a large debt encourages inflation, and if inflation is high, the debt will be serviced and ultimately paid off with cheaper real dollars in the future.

\subsubsection{Regression Result Analysis}

Table 4 showed the regression coefficients for the model estimating the impact of selected factors on real exchange rate using Pooled OLS. From the Table, the model shows that Gross Domestic Product (GDP) and Trade Openness (OPEN) were significant at $5 \%$ level in Pooled OLS estimation. This suggests that GDP and OPEN are good explanatory variables for determinants of real exchange rate in Ghana. The coefficients on the explanatory variables are negative (except GDP).

The model for the Pooled OLS is shown below:

The model for the REER

$$
\begin{aligned}
\operatorname{REER}_{t}= & -0.053-0.566 \mathrm{OPEN}_{t}-0.239 \mathrm{INFL}_{t}+0.493 \mathrm{GDP}_{t} \\
& -0.129 \mathrm{PUBLICDEBT}_{t}-0.462 \mathrm{TERMTRADE}_{t}+0.028 \mathrm{POL}_{t}+\varepsilon_{t}
\end{aligned}
$$

REER $=$ Real Exchange Rate, INF = Inflation, OPEN $=$ Trade Openness, POL $=$ Political Stability, PUBLICDEBT $=$ Public Debt, TERMTRADE = Term of Trade and GDP $=$ Gross Domestic Product.

Table 4. Regression coefficients for the model estimating the determinants of real exchange rate in Ghana using Pooled Least Squares (OLS).

\begin{tabular}{ccccc}
\hline REER & Coefficient & Standard Error & t-statistic & P value $(\mathrm{P}<0.05)$ \\
\hline C & -0.053 & 0.049 & -1.08 & 0.301 \\
OPEN & -0.566 & 0.184 & -3.08 & 0.011 \\
INFL & -0.239 & 0.201 & -1.19 & 0.239 \\
GDP & 0.493 & 0.230 & 2.14 & 0.054 \\
PUBLIC & -0.129 & 0.161 & -0.80 & 0.441 \\
TERMTRADE & -0.462 & 0.035 & -1.32 & 0.215 \\
POL & 0.028 & 0.060 & 0.47 & 0.650 \\
Adjusted R-squared & & & 0.412 & \\
R-squared & & 0.619 & \\
F-statistic & & 2.99 & \\
Prob (F-statistic) & & 0.055 & \\
No of observations & & & \\
\hline
\end{tabular}

*Significance level at 95\% Source Authors construct. 


\section{Conclusions and Policy Implication}

\subsection{Conclusions}

1) The study examined the development of Ghanaian foreign exchange market (i.e. real exchange rate) and the factors that influence its fluctuations. Foreign exchange market development in Ghana has been one of the contagious issues faced by the various governments since independence. Changes in exchange rate have various implications such as high rate of inflation, prices of goods and services, unemployment, low productivity and decline in investment.

2) The study analyzed the behavior of the foreign exchange market, the relationship between the foreign exchange market and its theoretical determinants. The importance of foreign exchange market was briefly reviewed in this study and is well known in the literature for both developed and developing economies.

3) Based on an extensive review of the literature on the determinants of the foreign exchange market, the background of the foreign exchange market system in Ghana and on data availability, an empirical model that linked the foreign exchange market to its potential determinants was specified. The variables used for the analyses were Gross Domestic Product (GDP growth), government public debt, trade openness, terms of trade, political stability and Inflation rate.

4) To analyze the determinants of real exchange rate in Ghana, the Ordinary Least Square method was chosen to the other techniques, because of its several advantages over those alternative techniques. In the application of methodology, the study started by analyzing the time series of the data employing both Correlation and Multicollinearity tests as well as overall significance of the model.

5) The variables were found to possess a very low degree of collinearity. The correlation results showed that only few variables (trade openness, GDP and political stability) correlated moderately with real exchange rate whereas the remaining showed weak correlation with real exchange rate.

6) The overall significance tests on the other hand show that F-test and adjusted R-squared in the model specifications provided evidence that the explanatory variables are jointly not equal to zero, therefore indicating a good fit of the model.

7) These findings, therefore, depict that foreign exchange market (real exchange rate) is subject to changes as a result of changes in the explanatory variables. The variable that has a long run relationship with the exchange rate was GDP growth. This means that increase in GDP growth is associated with a real appreciation of the exchange rate in Ghana. These results, therefore, support both the theoretical predictions and empirical results.

\subsection{Policy Implications}

1) The study used an OLS model to perform modeling real exchange rate against Gross Domestic Product (GDP growth), government public debt, trade openness, terms of trade, political stability and Inflation rate, and the mean equ- 
ation of the model was robust for modelling real exchange rate.

2) Similarly, the OLS model was found to be good for modeling volatility and forecasting real exchange rate.

3) Also, the research work has revealed that, the health of Ghana's economy is highly dependent on the strength of the Ghanaian currency: cedi against the foreign currencies since the country is import dependent, as such there must be a national agenda to increase foreign inflows and that introduction of several policies and intervention.

4) Furthermore, the forecast is an indication that policy makers and industry players can effectively plan to curb uncertainties in the Ghanaian economy given these models are used. There must be a national consensus to reduce imports into the country by improving production and in the long run increase non-traditional exports.

5) Last but not least, other economic indicators such as money supply, balance of payment and budget deficit could be added to inflation rate, exchange rate and interest for modelling using other regressions methods.

\section{Acknowledgements}

We extend our special gratitude to the developers, managers and funding agencies of World Bank Development Indicators (WDI) for granting access to these essential datasets in accordance to their specific data use and citation policies.

\section{Conflicts of Interest}

The authors declare no conflicts of interest regarding the publication of this paper.

\section{References}

[1] Adu, G., Karimu, A. and Mensah, J.T. (2015) An Empirical Analysis of Exchange Rate Dynamics and Pass through Effects on Domestic Prices in Ghana.

[2] Bawumia, M. and Abradu-Otoo, P. (2003) Monetary Growth, Exchange Rates and Inflation in Ghana: An Error Correction Analysis. Bank of Ghana Working Paper.

[3] Duttagupta, R. and Tolosa, G. (2007) Fiscal Discipline and Exchange Rate Arrangements: Evidence from the Caribbean. Emerging Markets Finance \& Trade, 43, 87-112. http://www.jstor.org/stable/27750579 https://doi.org/10.2753/REE1540-496X430605

[4] Chowdhury, M.T.H., Bhattacharya, P.S., Mallick, D. and Ulubaşoğlu, M.A. (2014) An Empirical Inquiry into the Role of Sectoral Diversification in Exchange Rate Regime Choice. European Economic Review, 67, 210-227. https://doi.org/10.1016/j.euroecorev.2014.02.001

[5] Afari-Opoku, M., Oliver, M. and Lloyd, T. (2004) Measuring the Real Effective Exchange Rate in Ghana. Centre for Research in Economic Development and International Trade, University of Nottingham Research Paper 04/11.

[6] Appiah, S.T. and Adetunde, I.A. (2011) Forecasting Exchange Rate between the Ghana Cedi and the US Dollar Using Time Series Analysis. Current Research Journal of Economic Theory, 3, 76-83. 
[7] Mumuni, Z. and Owusu-Afriyie, E. (2004) Determinants of the Cedi/Dollar Rate of Exchange in Ghana: A Monetary Approach. A Bank of Ghana Working Paper: WP/BOG-2004/06.

[8] Hassan, R., Chakraborty, S., Sultana, N. and Rahman, M.M. (2016) The Impact of the Real Effective Exchange Rate on Real Export Earnings in Bangladesh. Monetary Policy and Research Department, Bangladesh Bank.

[9] Uddin, K.M., Quaosar, G.A. and Nandi, D.C. (2013) Factors Affecting the Fluctuation in Exchange Rate of the Bangladesh: A Co-Integration Approach. The International Journal of Social Sciences, 18, 1-12.

[10] Sodersten, B. (1988) Internal Economics. Second Edition, Macmillan Education Ltd., London.

[11] Hill, C.W.L. (2010) International Business: Competing in the Global Market Place. McGraw-Hill Irwin, New York.

[12] Hill, C., Kwong, M., Bigman, D. and Taya, T. (2002) Floating Exchange Rates and the State of World Trade and Payments. Beard Books, New York, 144.

[13] Abbas, Z., Khan, S. and Syed Tahir Hussain, R. (2011) Exchange Rates and Macroeconomic Fundamentals: Linear Regression and Co-Integration Analysis on Emerging Asian Economies. International Review of Business Research Papers, 7, 250-263.

[14] Alagidede, P. and Ibrahim, M. (2016) On the Causes and Effects of Exchange Rate Volatility on Economic Growth: Evidence from Ghana. Working Paper. https://doi.org/10.1080/15228916.2017.1247330

[15] Insah, B. and Chiaraah, A. (2013) Sources of Real Exchange Rate Volatility in the Ghanaian Economy. Journal of Economics and International Finance, 5, 232. https://doi.org/10.5897/JEIF2013.0517

[16] World Bank. World Development Indicators. World Bank Publications. http://datatopics.worldbank.org/world-development-indicators/

[17] STATA (2019) STATA LLC US Home Page. https://www.stata.com

[18] Kutner, M.H., Nachtsheim, C.J. and Neter, J. (2004) Applied Linear Regression Models. 4th Edition, McGraw-Hill Irwin, New York. 